\title{
Somatotropin Measurement
}

National Cancer Institute

\section{Source}

National Cancer Institute. Somatotropin Measurement. NCI Thesaurus. Code C74792.

The determination of the amount of somatotropin hormone present in a sample. 